\title{
TOURISM IN THE FACE OF THE COVID-19 PANDEMIC. TOWARDS SUSTAINABLE REGIONAL DEVELOPMENT
}

\author{
Deimena Montvydaité丶 ${ }^{1}$, Daiva Labanauskaité ${ }^{2}$ \\ Klaipėda University (Lithuania)
}

\begin{abstract}
T\&T confirms its importance, as it contributes significantly to global GDP and creates jobs worldwide. These numbers began to decline as the Covid-19 pandemic struck the world, and more than $90 \%$ of the population came under restrictions. Travel restrictions and lockdowns hit the T\&T sector hard, responding together with economic indicators. International tourism is almost at a halt, and traditional, unsustainable business models are not working any more. In order to survive, the transformation of the T\&T sector is essential. This raises the question whether the crisis situation could not only have negative effects, but at the same time could be the moment for the long-needed chance to rethink tourism, considering a regional and more sustainable approach. As travel restrictions cover the world, the focus is on the regional level, the area that has the right to make territorially and regionally relevant decisions. The aim of the research is to evaluate the Covid-19 pandemic's effects on tourism, considering whether it could be a change towards sustainable regional development. Methods of analysis and synthesis of scientific literature, statistical data analysis, situation modelling, and logical conclusions are applied, to estimate the effects of the Covid-19 pandemic on tourism, to assess the challenges and opportunities in tourism in the face of the Covid-19 pandemic, and to evaluate possible changes in tourism towards sustainable regional development.
\end{abstract}

KEY WORDS: tourism, T\&T sector, Covid-19, pandemic, sustainable regional development.

JEL CODES: Z30, Z32, O18, L83.

DOI: http://dx.doi.org/10.15181/rfds.v34i2.2250

\section{Introduction}

The role of tourism in economic development is incontrovertible. The travel and tourism (T\&T) sector contributes remarkably to global Gross Domestic Product (GDP), and creates job places worldwide. According to data from the World Travel and Tourism Council (WTTC, 2020), as of 2019, the sector accounted for $10.3 \%$ of global GDP, and supported the livelihoods of 330 million people, creating one in four new jobs worldwide, and outpacing the growth of the global economy for the ninth consecutive year. Unfortunately, the situation transformed when the Covid-19 pandemic struck the world in early 2020. To limit the spread of Covid-19, governments across the globe have taken drastic measures, by locking down the entire country or the most affected cities, and also by prohibiting entry, resulting in an immense hit for the global tourism industry, particularly the travel and hospitality sector (Fotiadis et al., 2021). The pandemic has nearly brought the global tourism industry to a halt (Sharma et al., 2021). The WTTC (2020) estimates the impact of Co-

Deimena Montvydaitė - Klaipėda University, Faculty of Social Sciences and Humanities, Department of Economics, PhD candidate

Scientific interests: tourism, tourism economics, consumer behaviour, bio-business, development of the bio-economy, sustainable development

E-mail: deimenam@gmail.com

2 Daiva Labanauskaite - Klaipeda University, Faculty of Social Sciences and Humanities, Department of Economics, associate professor, doctor of economics

Scientific interests: tourism, service economics and marketing, marketing research, green economy, blue economy, business project evaluation

E-mail: labanauskaite.daiva@gmail.com 
vid-19 on the T\&T sector: according to data of November 2020, 142.6 million jobs were lost in 2020 (a 43\% decline) as a result of the pandemic. Moreover, a $\$ 3,815$ billion loss in T\&T in global GDP is counted (43\% decline). It is also estimated that international global arrivals have already declined by $65 \%$, while at the same time domestic travel arrivals declined by $33 \%$. If nothing is done to improve this situation, these losses are expected to get even higher. The unsustainable practices of the tourism industry did not help the cause of sustainable living worldwide (Sharma et al., 2021). Therefore, with the enormity of the Covid-19 outbreak, it is not essential to go back to business as usual when the pandemic ends; rather, it can be a chance to reevaluate the transformation of the overall tourism system for sustainability (Gossling et al., 2020). In the face of the pandemic, a sustainable regional approach may not only be a way for the sector to survive the Covid-19 crisis, but also a step towards a more sustainable future in economic, socio-cultural and environmental terms. Consequently, the research question how the Covid-19 pandemic will affect tourism, and whether it could be a change towards sustainable regional development, is raised.

The problem of the research. When the Covid-19 pandemic struck the world, the T\&T sector was the first to feel the effects. It was in a precarious position. Traditional tourism business models stopped working. Travel restrictions and lockdowns were a hard hit for the sector, which contributes significantly to global economic development. Tourism numbers dropped sharply, responding together with economic indicators. The predictions for tourism and economic losses show that in order to survive, the transformation of the T\&T sector is essential. This raises the question that maybe the crisis situation might have not only negative effects, but at the same time might be the moment for a long-needed change to rethink tourism, considering a regional and more sustainable approach.

The aim of the research: to evaluate the effects of the Covid-19 pandemic on tourism, considering whether it could change towards sustainable regional development.

Research object: the effects of the Covid-19 pandemic on tourism, considering whether it could change towards sustainable regional development.

Research tasks:

- to estimate the effects of the Covid-19 pandemic on tourism;

- to assess the challenges and opportunities in tourism in the face of the Covid-19 pandemic;

- to evaluate possible changes in tourism towards sustainable regional development.

Research methods: analysis and synthesis of scientific literature, analysis of statistical data, situation modelling, logical conclusions.

\section{The effects of the Covid-19 pandemic on tourism}

In times of services-led growth trends, the T\&T industry has become increasingly important worldwide since 1990. T\&T's direct contribution to world GDP increased from $9.9 \%$ in 1995 to $10.3 \%$ in 2019 . The significant impact on the T\&T sector is also visible in employment levels. The total contribution to world employment in 2019 was $10.4 \%$ (Sharma et al., 2021). Besides tourism's remarkable contribution to the global economy and development, in many places tourism has also become a strategic pillar industry, given its increasingly significant contribution to local GDP (Zhang et al., 2021). Goodwin and Wilson (2004) add that the potential for tourism to contribute significantly to the alleviation of poverty is considerable. However, despite its importance, tourism is also one of the most vulnerable industries (Zhang et al., 2021). As the Covid-19 pandemic struck the world, and it came to a standstill, so did T\&T, a sector which not only accounts for over $10 \%$ of global GDP, but for one in ten jobs on the planet, and one in four new jobs created globally in the last five years (WTTC, 2020).

In the space of months, the framing of the global tourism system moved from overtourism to non-tourism (Gossling et al., 2020). The global spread and impact of Covid-19 is unlike anything society has faced before, with a complex and devastating amalgamation of health, economic and social issues (WTTC, 2020). Since late 2019, the Covid-19 pandemic has caused unprecedented global health and social emergencies, and had profound negative impacts on the global economy (Zhang et al., 2021). The impact of the Covid-19 pandemic on the T\&T sector has been estimated by the WTTC (2020). The main effects and losses are illustrated in Figure 1. 


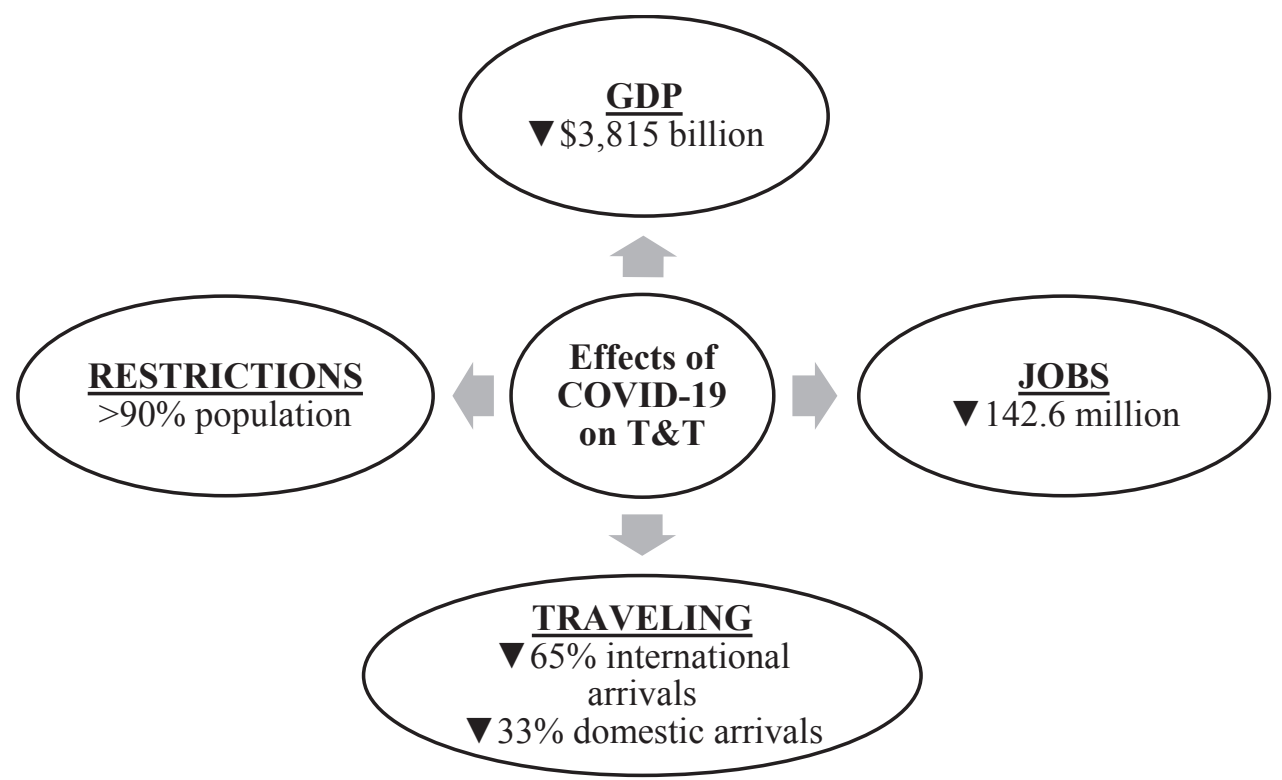

Figure 1. The main effects of the Covid-19 on tourism in numbers

Source: compiled by the authors, based on WTTC (2020), and Gossling et al. (2020).

Figure 1 presents the main effects of Covid-19 on the tourism sector, according to data from November 2020. The figure shows that more than $90 \%$ of the world's population is under restrictions, and reveals that, as a result of the pandemic, 142.6 million jobs have been lost, and a $\$ 3,815$ billion loss has been accounted for in T\&T in global GDP. It is also estimated that international global arrivals have declined by $65 \%$, while domestic travel arrivals have dropped by $33 \%$. If nothing is done to improve the situation, the numbers are expected to reach losses of 174.4 million jobs and $\$ 4,711$ billion global GDP, as well as $73 \%$ of international and $45 \%$ of domestic arrivals (WTTC, 2020). Single countries also estimate and forecast that domestic tourism will suffer less than international tourism (OECD, 2020). For example, in Germany, annual booked turnover compared to 2019 is expected to decline by $42 \%$ in domestic, and $57 \%$ in international tourism in $2020,14 \%$ in domestic and 52\% in international tourism in 2021, and 30\% in international tourism in 2022 . Switzerland estimates that the slump in domestic demand is forecast to be relatively small, down by $14 \%$, with the loss in international business significant, down by 55\%. Domestic and European demand there is expected to recover steadily, but demand from overseas markets is not expected to recover until 2023. In the United Kingdom, inbound tourism arrivals are forecast to decline by $73 \%$, with a corresponding decline in spending of $79 \%$, while domestic tourism is expected to decline by $49 \%$ in trips and spending. The research by Arbulu et al. (2021) shows that although Spanish domestic tourism is expected to fall by $42.64 \%$ compared to 2019 due to the loss of income and the fear of travelling, it may still generate $33 \%$ of pre-crisis overnight stays, assuming that $50 \%$ of outbound tourism can be reoriented to the domestic market. The research reveals that at the regional level, the potential of domestic tourism varies significantly, and may generate from $10 \%$ of pre-crisis overnight stays in the Balearic Islands and the Canary Islands to $70 \%$ in Castille-La Mancha. This figure depends on the traditional orientation of a region's portfolio on the domestic market, the volatility of its domestic demand, and the capacity to attract new segments of domestic tourists.

Regional data of the main losses caused by the Covid-19 pandemic on T\&T are shown in Table 2. 
Table 1. A regional overview of the effects of Covid-19 on T\&T

\begin{tabular}{|c|c|c|}
\hline Region & T\&T GDP change 2020 & T\&T change in jobs 2020 \\
\hline Africa & $-49.2 \%(-\$ 83 \mathrm{BN}$ USD) & $-29.3 \%(-7.2 \mathrm{MN}$ jobs $)$ \\
\hline Asia Pacific & $-53.7 \%(-\$ 1,645$ BN USD) & $-18.4 \%(-34.1 \mathrm{MN}$ jobs $)$ \\
\hline Caribbean & $-58.0 \%(-\$ 34$ BN USD) & $-24.7 \%(-0.7 \mathrm{MN}$ jobs $)$ \\
\hline Europe & $-51.4 \%(-\$ 1,126$ BN USD) & $-9.3 \%(-3.6 \mathrm{MN}$ jobs $)$ \\
\hline Latin America & $-41.1 \%(-\$ 110$ BN USD) & $-23.4 \%$ (-4.0 MN jobs) \\
\hline Middle East & $-51.1 \%(-\$ 138$ BN USD) & $-17.4 \%(-1.2 \mathrm{MN}$ jobs $)$ \\
\hline North America & $-42.2 \%(-\$ 910$ BN USD) & $-27.9 \%(-7.1 \mathrm{MN}$ jobs $)$ \\
\hline
\end{tabular}

Source: WTTC (2021).

Table 2 illustrates the effect of the Covid-19 pandemic on T\&T as the change in GDP and the change in jobs in 2020 regionally. It reveals that the biggest loss in GDP was in the Asia Pacific region $(\$ 1,645$ billion US\$) and in Europe (-\$1,126 billion US\$). Evaluating the percentage change, the Caribbean and Asia Pacific were the regions that suffered from the biggest decline in GDP (-58.0\% and $-53.7 \%$ respectively). Looking at the job situation, Africa and North America have suffered the most. Here, the loss in jobs reaches respectively 7.2 million jobs, which means a $29.3 \%$ decline, and 7.1 million jobs, which means a decline of $27.9 \%$. Summing up, all regions have been affected by the Covid-19 pandemic, and the stagnant tourism has responded to the economy and development.

These statistics again confirm that tourism is among the industries most negatively affected by the pandemic (Zhang et al., 2021). UNWTO (2020) has found that 93\% of destinations in Europe have fully closed their borders to international tourism. In America, the proportion reaches 82\%, in Asia and the Pacific 77\%, in the Middle East 70\%, and in Africa 60\%. Gossling et al. (2020) argue that by using country population data, it can be estimated that over $90 \%$ of the world's population is in countries with some level of international travel restrictions, and many of these countries also have some degree of restrictions on internal movement, including limited air travel and stay-at-home orders. It was predicted that all efforts conducted by many countries in the world en masse to prevent its spread, such as social distancing, self-isolation and actions similar to lockdown, may have a major impact on tourism demand in many countries (Haryanto, 2020). The decision which regions to quarantine directly affects a country's economy. It can affect all areas of trade, especially tourism and the supply chain (Altuntas, Gok, 2021). International tourist arrivals in the period January to October 2020 globally experienced a drop of $72 \%$, and declined regionally by $82 \%$ in Asia and the Pacific region, 73\% in the Middle East, 69\% in Africa, and 68\% in the Americas and Europe (UNTWO, 2020). The Covid-19 pandemic changes the overall business situation all over the world. Tourist numbers are falling dramatically, revenue is shrinking, and people are losing their jobs: this is a realistic depiction of the tourism industry (Deb, Nafi). The WTTC (2020) assesses that the slowdown in T\&T will have devastating ripple effects beyond the sector itself. It is clear that the great lockdown and shutdown of tourism-related businesses and supporting businesses following the Covid-19 pandemic have resulted in an unprecedented socio-economic impact (Fotiadis et al., 2021).

Deb and Nafi (2020) estimate that the effects of the Covid-19 pandemic crisis on the tourism sector may be more harmful than any other previous shock. The authors believe that the consequences may be felt for the next two or three years. Skare et al. (2021) estimate that in the optimistic and unlikely scenario of an end to all lockdowns, the world economy will take about one quarter period to achieve a new balance. If partial lockdowns persist, the recovery time will likely be much longer. Kaushal and Srivastava (2021) argue that the Covid-19 pandemic continues to thwart the sector, and raises serious questions about the present and future survival of the sector.

All these scientific insights and estimated losses show that the Covid-19 pandemic has undeniable effects on tourism, and consequently on the global economy and development. It is clear that the old model of the 
world, including business models, travelling habits, social space, etc, will not work any more. Therefore, on the other hand, the question arises, maybe this crisis situation might have another approach, and this challenging time could also bring some opportunities for future development.

\section{Challenges and opportunities in tourism in the face of the Covid-19 pandemic}

The analysis has revealed that in this crisis situation, the T\&T sector faces a lot of challenges, which also applies to other industries and to the global economy and development. However, on the understanding that to survive these hard times there is a need to change, it is important to look for a different approach. Besides the negative effects of the Covid-19 pandemic and the losses caused in the main tourism and economic indicators, could there be any positive points and opportunities?

Estimating the impact and outcomes of the Covid-19 pandemic, the World Tourism Organization UNTWO (2020) has made a SWOT analysis of the T\&T sector in the face of Covid-19 (Table 2).

Table 2. SWOT analysis of T\&T in the face of Covid-19

\begin{tabular}{|c|c|c|}
\hline Positive & Negative & \\
\hline Strengths & Weaknesses & \\
\hline $\begin{array}{l}\text { - Proven resilience of tourism in past crises } \\
\text { - Domestic tourism can be a buffer } \\
\text { - Adaptation capacity: safety and hygiene protocols, } \\
\text { trips closer to home, value for money, responsible } \\
\text { consumer behaviour } \\
\text { - Government support for the sector }\end{array}$ & $\begin{array}{l}\text { - Segments potentially affected are also high } \\
\text { spenders: international, long haul, business travel } \\
\text { and events } \\
\text { - Major disruption in the airline industry with airline } \\
\text { failures and concentration } \\
\text { - Lack of references in previous downturns } \\
\text { - Perception of travel as a risk } \\
\text { - Low levels of demand when restarting tourism due } \\
\text { to social distancing }\end{array}$ & 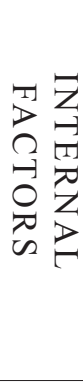 \\
\hline Opportunities & Threats & \\
\hline $\begin{array}{l}\text { - Re-think business model } \\
\text { - Innovation and digitalisation } \\
\text { - Sustainability and sustainable-oriented segments } \\
\text { - De-escalation phases initiated by several countries } \\
\text { toward the 'new normal' } \\
\text { - Progress in adaptation plans in destinations \& } \\
\text { companies }\end{array}$ & $\begin{array}{l}\text { - Economic environment: world recession, rising } \\
\text { unemployment and jobs at risk, closure of } \\
\text { businesses, mainly SMEs, disposable income, } \\
\text { uncertainty weighing on consumer and business } \\
\text { confidence } \\
\text { - Uncertain length of pandemic (including } \\
\text { resurgence) and vaccine unavailability } \\
\text { - Extent of lockdowns and travel restrictions } \\
\text { - Unknown form of the 'new normal' }\end{array}$ & 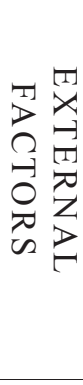 \\
\hline
\end{tabular}

Source: UNTWO (2020).

The table shows that the Covid-19 pandemic has brought not only challenges, but opportunities as well. Behind the weaknesses, such as the loss of affected spenders' income, the disruption in the airline industry, the lack of information, the risky travelling, and low levels of demand, the positive effects and the main strengths show the resilience of tourism, highlight the importance of domestic tourism, reveal the adaptation capacity, and remind governments to support the sector. As well as the threat of a world recession, rising unemployment and jobs at risk, closures of business, less disposable income, uncertainty weighing on consumer and business confidence, the unclear length of the pandemic and the question of vaccine availability, and as well as the extent of lockdowns and travel restrictions and the unknown form of the 'new normal', there are opportunities, like re-thinking the business model, innovation and digitalisation, de-escalation phases initiated by several countries toward the 'new normal', progress in adaptation plans in destinations and companies, and, what is the most important in the field of this research, sustainability and sustainably oriented se- 
gments (rural, nature, health). Brouder et al. (2020) discuss the 'new normal', and consider it as the question as to how, in a post-lockdown world, tourism will be reestablished in a crippled global economy. The authors add that Covid-19 presents an opportunity for the tourism industry to pause and consider what we want out of the post- Covid-19 tourism landscape, focusing on the economic, but also socio-cultural and environmental aspects of the industry. The Organisation for Economic Co-operation and Development (OECD, 2020) adds that, besides the negative impact of Covid-19, there could be a positive approach, as the pandemic is also triggering innovation in the sector, and new opportunities in business model and service delivery innovation, which also includes innovations catering to new trends in demand, for example from the domestic market, and in rural destinations and natural areas.

The consequent impact on the T\&T sector requires unparalleled cooperation and multifaceted solutions to support T\&T through this crisis and enhance the sector's resilience to future shocks (WTTC, 2020). It is believed that behind the challenges, the situation will give an opportunity to think about the current business structure of the tourism industry, which may need to reform to address the crisis moment, to protect businesses, and to protect jobs (Deb, Nafi, 2020). Tourism is at a crossroads, and the measures put in place today will shape the tourism of tomorrow (OECD, 2020). As Brouder (2020) states, this time, however, the reset has the potential to be transformative. The OECD (2020) argues that governments need to consider the longer-term implications of the crisis, while capitalising on digitalisation, supporting low carbon transition, and promoting the structural transformation needed to build a stronger, more sustainable and resilient tourism economy.

The analysis has confirmed that Covid-19 brought controversial impacts on the tourism sector, posing challenges and at the same time opening up opportunities for change. It is revealed that tourism is at a crossroads, and the survival of the sector requires a transformation. The next question is what could the possible changes be, and whether this situation could lead towards the more sustainable future of the sector itself, and more sustainable development in a broader perspective.

\section{Possible changes in tourism towards sustainable regional development}

The decline in tourism has not always been unwelcome, as while destinations may miss the revenue from tourism and the services it supports, the crisis provides an opportunity to manage a recovery to avoid returning to the pre-crisis situation, which was putting pressure on infrastructures, the environment and local populations (OECD, 2020).

The crisis is an opportunity to rethink tourism for the future (OECD, 2020). It is an opportunity to take advantage of new technologies, implement green recovery strategies, and shift to policy and business practices that better balance the environmental, social and economic impacts of tourism. Policy makers should leverage the opportunity to reboot the tourism economy on a stronger, fairer and more sustainable footing (OECD , 2020). The reset that was hoped for with eco-tourism, sustainable tourism, etc, may finally have the institutional alignment it needs to succeed globally (Brouder, 2020). Buttler (1999) claims that sustainable tourism is tourism which is developed and maintained in the area (community, environment) in such a manner and on such a scale that it remains viable over an indefinite period, and does not degrade or alter the environment (human and physical) in which it exists to such a degree that it prohibits the successful development and well-being of other activities and processes. The World Tourism Organization (WTO, 2005) argues that sustainable tourism should: make optimal use of environmental resources that constitute a key element in the development of tourism, maintaining essential ecological processes and helping to conserve the natural heritage and biodiversity; respect the socio-cultural authenticity of host communities, conserve their built and living cultural heritage and traditional values, and contribute to inter-cultural understanding and tolerance; ensure viable, long-term economic operations, providing socio-economic benefits to all stakeholders that are fairly distributed, including stable employment and income-earning opportunities and social services to host communities, and contributing to the alleviation of poverty. On the other hand, unsustainable tourism could be defined as the opposite of sustainable tourism. Unsustainable tourism refers to tourism that fails to conser- 
ve tourist resources, and/or does not support the lives and culture of local people (Burdett, 2018). Therefore, it confirms that tourism, transformed into a more sustainable form, could be a step forwards, going in a more sustainable direction of development.

It is estimated that the tourism sector will be very different in 2021 to what it was in 2019 (OECD, 2020). As the lockdowns in many countries, widespread travel restrictions, and airport and national border closures reduced the number of international tourist arrivals (Zhang et al., 2021), domestic tourism is set to return faster than international travel (Singh, Mir, 2020). A salient feature of the Covid-19 pandemic has been the sharp and deep decline in mobility, which has caused a slump in tourism, trade in travel services and consumption by non-residents (European Central Bank, 2020). In these pandemic terms, domestic tourism is considered as the possible solution for the tourism sector to survive and revive. The OECD (2020) adds that domestic tourism is providing a much-needed boost to help sustain many tourism destinations and businesses, and will continue to be a key driver of recovery in the short-to-medium term. It is evaluated that there has been some pick-up in domestic tourism activities, due in part to the displacement effects of international travel restrictions. The UNTWO (2020) highlights the potential of domestic tourism to help drive economic recovery, as in most destinations domestic tourism generates higher revenues than international tourism. In OECD nations, domestic tourism accounts for $75 \%$ of total tourism expenditure, while in the European Union, domestic tourism expenditure is 1.8 times higher than inbound tourism expenditure. Globally, the largest domestic tourism markets in terms of expenditure are the United States with nearly US\$ 1 trillion, Germany with US\$ 249 billion, Japan with US\$ 201 billion, the United Kingdom with US\$ 154 billion, and Mexico with US\$ 139 billion. The WTTC (2018) emphasises that, while countries often tend to focus on international tourism due to the revenue earned through exports, domestic tourism remains the leading form of tourism, representing an important tool for regional economic growth and development. Trying to mitigate the effects of the Covid-19 pandemic, countries are implementing policies related to the promotion of domestic tourism, reflecting its crucial contribution to travel and tourism in major economies, and a common industry expectation that domestic travel will recover before inbound travel (Arbulu et al., 2021).

According to Wen (2020), who researched the post-Covid-19 Chinese domestic tourism market recovery, at this time, options for domestic tourism can provide Chinese residents with an accessible means of travel, as many countries continue with lockdowns in the face of Covid-19. Therefore, apart from the Chinese government's strategies to control and prevent the spread of the virus (e.g. travel restrictions), other lenses through which China's residents may be inspired to engage in domestic tourism are provided. For instance, Malaysia is now turning to domestic tourism to offset the fall in international arrivals. To boost domestic tourism, several measures, such as personal income tax relief for domestic tourism and digital vouchers for domestic flights, rail travel and hotel accommodation, are offered (Foo et al., 2020). Adam and Kimbu (2020) argue that domestic and regional tourism must be critical components in recovery strategies for African tourism. The Covid-19 pandemic highlights the need for an expanded understanding of the nature of domestic and regional tourism across the continent (Rogerson, Baum, 2020). Moreno-Luna et al. (2021) claim that the evolution of domestic tourism in Spain could be a great hope for the country's resilience and, with the right measures, it could favour a change in the tourism development model of countries like Spain, focusing more on sustainable, less intensive proposals, with less impact on the population and the environment. Authors emphasise that domestic tourism represents an opportunity for all regions. Projecting the pandemic-initiated changes, Brouder (2020) suggests if, for instance, with destination management, marketing organisations start to take a regional approach (international travel is now beaten by the often downplayed domestic and nearest neighbour markets), at the same time as unprecedented turbulence in tourism entrepreneurship (long standing businesses disappearing and new ones emerging), we may begin to see destinations re-emerge with an altogether different focus. In other words, there may be an institutional reckoning on the demand side of tourism, as we emerge from the Covid-19 pandemic: as the changed behaviour of people creates new norms, the tourism sector may need to come to terms with more locally oriented, environmentally conscious tourists. Sustainability may become more prominent in tourism choices, due to greater awareness of climate change and adverse impacts of tourism (OECD, 2020). The research work by Moreno-Luna et al. (2021) shows the importance of domestic tourism alleviating the ravages of the health and socioeconomic crisis, with rural and camping types of accommodation leading 
visitors' choices. This is evidence of one of the most appropriate options for the development of sustainable tourism, providing quality of life for residents and safety for tourists. The research data shows a faster recovery of domestic tourism than that experienced in international tourism, which is an opportunity for regions that are not tourism leaders, although they have been developing alternative offers linked to rural tourism; these regions are those which in this pandemic have focused their strategies on the promotion of domestic tourism. Facing the Covid-19 pandemicinitiated changes, T\&T has a unique ability to further protect and engage vulnerable groups, while reducing poverty and inequality. This is a time for the sector to accelerate the meaningful changes that will make a lasting difference for future generations (WTTC, 2020). In summarising, the crisis and the recovery plans that are being put in place are a once-in-a-lifetime opportunity to move towards more sustainable and resilient models of tourism development (OECD, 2020). As almost the whole population live under travel and other pandemic-related restrictions that especially influence the international market, the focus is on the local, regional level. Therefore, the Covid-19-initiated changes and opportunities are considered on a regional level. In the context of this study, a region is understood as a territory with appropriate authority and the right to make territorially and regionally relevant decisions. In the face of the Covid-19 pandemic, considering the right to take decisions relevant to the restrictions, it could be the continent level, country level, municipality level or even city level. Figure 2 illustrates the framework of changes in the face of Covid-19 towards sustainable regional development.

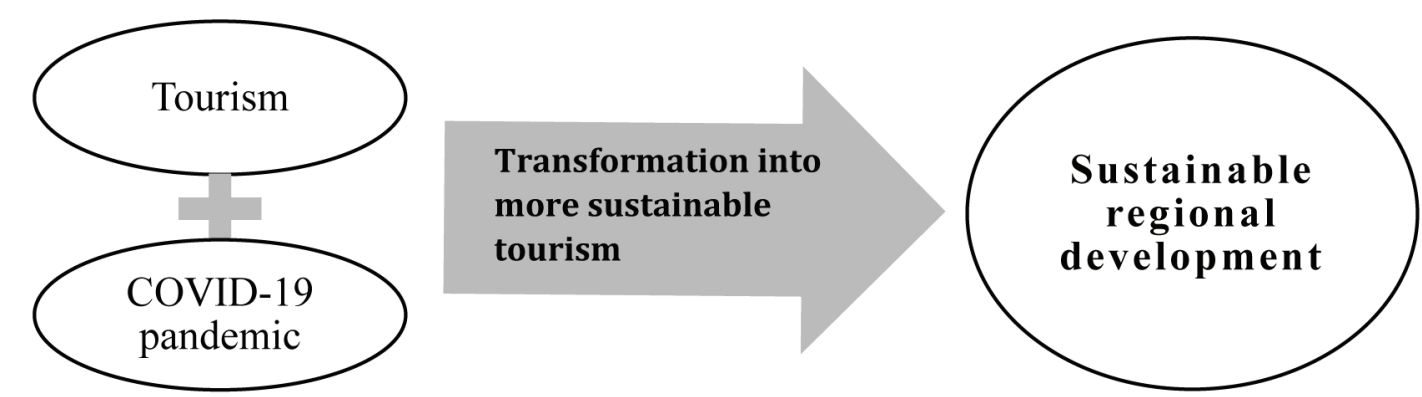

Figure 2. The framework of changes in the face of Covid-19 towards sustainable regional development

Source: compiled by the authors.

Figure 2 shows how Covid-19 pandemic-affected tourism transforms into more sustainable tourism that leads towards sustainable regional development. This framework illustrates the answer to the main research question of how the Covid-19 pandemic will affect tourism, and whether it could be a change towards sustainable regional development. The analysis has revealed the controversial effects of Covid-19 on tourism, and disclosed the pandemic-initiated opportunities for changes towards more sustainable regional development.

\section{Conclusions}

The analysis confirms that the Covid-19 pandemic has had wide effects on the tourism sector, and consequently on all the economy and development. The effects can be seen globally and regionally. As more than $90 \%$ of the world's population is under the restrictions (Gossling et al., 2020), it results in falling numbers in T\&T in global GDP, in jobs, and in tourist arrivals, both international and domestic. The old model of the world, including traditional business models, travel habits, social space, etc, are not working any more. However, the research confirmed that Covid-19 has had a controversial impact on the tourism sector, posing challenges and at the same time opening up opportunities for change. As the world grapples with the realities of the global pandemic, there is an opportunity to rethink exactly what tourism will look like in the decades ahead (Brouder, 2020). This crisis situation, besides the challenges to the tourism sector, also provides oppor- 
tunities to encourage innovation, drive new business models, explore new niches or markets, open up new destinations, and move to more sustainable and resilient tourism development models (OECD, 2020). The pandemic will contribute to creating new business models, which will essentially determine the industry's chances of survival, by transforming it into a much more sustainable form (Sharma et al., 2021). As the world is under restrictions, it especially affects international travel; therefore, the focus is on the local, regional level. In the context of this study, a region is understood as a territory with appropriate authority and the right to make territorially and regionally relevant decisions. Evaluating the trends in international and domestic tourism in the face of the pandemic, it is estimated that during the pandemic and post- Covid-19, domestic tourism is dominating, with most travellers coming from nearby areas (Haywood, 2020). It is believed that the feeling of belonging among locals will dictate terms for the revival of the tourism industry (Sharma et al., 2021). Thus, as the Covid-19 pandemic has slowed the development of the old model of unsustainable mass, and especially from a socio-cultural and environmental approach, damaging tourism, the crisis situation could be the starting point for the transformation of tourism towards a more sustainable existence. The future of tourism and the 'new normal' could be related to a more sustainable way of thinking and travelling, as travellers, with respect to the Covid-19 pandemic restrictions, prefer to choose local, regional destinations, less damaging transport, and the preservation of the local cultural and natural environment. With the more sustainable way of thinking of travellers, and the support and cooperation of local or regional government, in the face of the Covid-19 pandemic, tourism could revive into a more sustainable form, contributing to sustainable regional development. Therefore, as local, regional-level trips and domestic tourism in these difficult times seem to be the only way of travelling, and the Covid-19 pandemic is considered to be a time for the transformation of the tourism sector, the answer to the main research question, whether the effects of the Covid-19 pandemic on tourism could be a change towards sustainable regional development, is positive.

Concluding briefly, besides the negative effects and the challenges, the Covid-19 pandemic also has a positive approach, considering the future of tourism, as it is the opportunity for a change towards a more sustainable future of tourism, contributing to sustainable regional development.

These findings, confirming that the Covid-19 pandemic could be an opportunity for a change in the tourism sector towards more sustainable regional development, could be a basis for further research, investigating possible solutions in the transformation of the tourism sector. The research could be expanded by a more detailed analysis of local and regional governments' actions mitigating the effects of the Covid-19 pandemic on the tourism sector and the whole economy, reviving the sector, and transforming it for the future, aiming for sustainable regional development.

\section{References}

Adam, I., Kimbu, A. N. (2020). Strategies Africa's tourism requires to manage blow from coronavirus. The Conversation, Vol. 23. Internet access: https://theconversation.com/strategies-africas-tourism-requires-to-manage-blowfrom-coronavirus-135858.

Altuntas, F., Gok, M. S. (2021). The effect of COVID-19 pandemic on domestic tourism: A DEMATEL method analysis on quarantine decisions. International Journal of Hospitality Management, Vol. 92, p. 1-9. Doi: https://doi. org/10.1016/j.ijhm.2020.102719.

Arbulú, I., Razumova, M., Rey-Maquieira, J., Sastre, F. (2021). Can domestic tourism relieve the COVID-19 tourist industry crisis? The case of Spain. Journal of Destination Marketing \& Management, Vol. 20, p. 1-12. Doi: https:// doi.org/10.1016/j.jdmm.2021.100568.

Brouder, P. (2020). Reset redux: possible evolutionary pathways towards the transformation of tourism in a COVID-19 world. Tourism Geographies, Vol. 22(3), p. 484-490. Doi: https://doi.org/10.1080/14616688.2020.1760928.

Brouder, P., Teoh, S., Salazar, N. B., Mostafanezhad, M., Pung, J. M., Lapointe, D., (...) Clausen, H. B. (2020). Reflections and discussions: tourism matters in the new normal post COVID-19. Tourism Geographies, Vol. 22(3), p. 735-746. Doi: https://doi.org/10.1080/14616688.2020.1770325.

Burdett, M. (2018). Unsustainable tourism and carrying capacity. Internet access: https://www.geographycasestudy. com/consequences-of-unsustainable-tourism/.

Buttler, R. W. (1999). Sustainable tourism: A state- of- the- art review. Tourism Geographies, Vol. 1(1), p. 7-25. Doi: https://doi.org/10.1080/14616689908721291. 
Deb, S. K., Nafi, S. (2020). Impact of Covid-19 Pandemic on Tourism: Recovery Proposal for Future Tourism. GeoJournal of Tourism and Geosites, Vol. 33(4), p. 1486-1492. Doi: https://doi.org/10.30892/gtg.334spl06-597.

European central Bank. (2020). Economic and monetary developments. Internet access: https://www.ecb.europa.eu/ pub/economic-bulletin/html/eb202008.en.html.

Foo, L. P., Chin, M. Y., Tan, K. L., Phuah, K. T. (2020). The impact of COVID-19 on tourism industry in Malaysia. Current Issues in Tourism, p. 1-5. Doi: https://doi.org/10.1080/13683500.2020.1777951.

Fotiadis, A., Polyzos, S., Huan, T. C. T. (2021). The good, the bad and the ugly on COVID-19 tourism recovery. Annals of Tourism Research, Vol. 87, p. 1-14. Doi: https://doi.org/10.1016/j.annals.2020.103117.

Goodwin, N., Wilson, S. (2004). Tourism and Local Economic Development. How can businesses in travel and tourism increase the contribution of the industry to local economic development and pro-poor growth? Internet access: https://www.haroldgoodwin.info/resources/Flyer_Final.pdf.

Gossling, S., Scott, D., Hall, M. (2020). Pandemics, tourism and global change: a rapid assessment of COVID-19. Journal of Sustainable Tourism, Vol. 29(1), p. 1-20. Doi: https://doi.org/10.1080/09669582.2020.1758708.

Haryanto, T. (2020). Editorial: Covid-19 Pandemic and International Tourism Demand. Journal of Developing Economies, Vol. 5(1), p. 1-5. Doi: http://dx.doi.org/10.20473/jde.v5i1.19767.

Haywood, K. M. (2020). A post COVID-19 future-tourism re-imagined and re-enabled. Tourism Geographies, Vol. 22(3), p. 599-609. Doi: https://doi.org/10.1080/14616688.2020.1762120.

Kaushal, V., Srivastava, S. (2021). Hospitality and tourism industry amid COVID-19 pandemic: Perspectives on challenges and learnings from India. International journal of hospitality management, Vol. 92, p. 1-9. Doi: https://doi. org/10.1016/j.ijhm.2020.102707.

Moreno-Luna, L., Robina-Ramírez, R., Sánchez, M. S. O., Castro-Serrano, J. (2021). Tourism and Sustainability in Times of COVID-19: The Case of Spain. International Journal of Environmental Research and Public Health, Vol. 18(4), p. 1-21. Doi: https://doi.org/10.3390/ijerph18041859.

OECD. (2020). Mitigating the impact of COVID-19 on tourism and supporting recovery. Doi: https://doi. org/10.1787/47045bae-en.

OECD. (2020). Rebuilding tourism for the future: COVID-19 policy responses and recovery. Doi: https://doi. org/10.1787/bced9859-en.

Rogerson, C. M., Baum, T. (2020). COVID-19 and African tourism research agendas. Development Southern Africa, Vol. 37(5), p. 727-741. Doi: https://doi.org/10.1080/0376835X.2020.1818551.

Sharma, G. D., Thomas, A., Paul, J. (2021). Reviving tourism industry post-COVID-19: A resilience-based framework, Tourism management perspectives, Vol. 37, p. 1-11. Doi: https://doi.org/10.1016/j.tmp.2020.100786

Singh, R., Mir, M. A. (2020). Empirical Examination of the Impact of Environmental Responsible Tourism Practices on the Destination Sustainability. e-Review of Tourism Research, Vol. 17(6), p. 837-864.

Skare, M., Soriano, D. R., Porada-Rochon, M. (2021). Impact of COVID-19 on the travel and tourism industry, Technological Forecasting and Social Change, Vol. 163, p. 1-14. Doi: https://doi.org/10.1016/j.techfore.2020.120469.

UNTWO. (2020). Impact Assessment of The Covid-19 Outbreak on International Tourism. Internet access: https:// www.unwto.org/impact-assessment-of-the-covid-19-outbreak-on-international-tourism.

UNTWO. (2020). UNTWO Highlights Potential of Domestic Tourism to Help Drive Economic Recovery in Destinations Worldwide. Internet access: https:/www.unwto.org/news/unwto-highlights-potential-of-domestic-tourism-tohelp-drive-economic-recovery-in-destinations-worldwide.

Wen, J., Wang, C. C., Kozak, M. (2021). Post-COVID-19 Chinese domestic tourism market recovery: potential influence of traditional Chinese medicine on tourist behaviour. Anatolia, Vol. 32(1), p. 121-125. Doi: https://doi.org/10 $.1080 / 13032917.2020 .1768335$.

WTO. (2005). Making Tourism More Sustainable - A Guide for Policy Makers. Internet access: https://www.e-unwto. org/doi/book/10.18111/9789284408214.

WTTC. (2018). Domestic Tourism Importance and Economic Impact. Internet access: https://wttc.org/Portals/0/Documents/Reports/2018/Domestic\%20Tourism-Importance\%20Economic\%20Impact-Dec\%2018. pdf?ver=2021-02-25-182514-683.

WTTC. (2020). To Recovery \& Beyond, The Future of Travel \& Tourism, in The Wake of Covid-19. Internet access: https://wttc.org/Research/To-Recovery-Beyond.

WTTC. (2020). Travel \& Tourism Recovery Scenarios 2020 \& Economic Impact from Covid-19. Internet access: https://wttc.org/Portals/0/Documents/Reports/2020/Global\%20Recovery\%20Scenarios\%20Nov\%202020. pdf?ver=2021-02-25-183017-943.

WTTC. (2021). Economic Impact reports. Regional Overview 2020. Internet access: https://wttc.org/Research/Economic-Impact.

Zhang, H., Song, H., Wen, L., Liu, C. (2021). Forecasting tourism recovery amid COVID-19. Annals of Tourism Research, Vol. 87, p. 1-16. Doi: https://doi.org/10.1016/j.annals.2021.103149. 


\title{
TURIZMAS COVID-19 PANDEMIJOS AKIVAIZDOJE. TVARAUS REGIONINIOVYSTYMOSI LINK
}

\author{
Deimena Montvydaité, Daiva Labanauskaité \\ Klaipėdos universitetas (Lietuva)
}

\section{Santrauka}

Turizmo vaidmuo kalbant apie ekonominę plètrą - neginčijamas. Kelionių ir turizmo sektorius reikšmingai prisideda prie globalaus bendrojo vidaus produkto (BVP) generavimo ir kuria darbo vietas visame pasaulyje. Remiantis Pasaulio kelionių ir turizmo tarnybos (WTTC, 2020) duomenimis, 2019 m. šis sektorius sudarė 10,3 \% pasaulio BVP, palaikė 330 milijonų darbo vietų, kartu sukurdamas kas ketvirtą naują darbo vietą visame pasaulyje bei devintus metus iš eilès augdamas sparčiau negu pasaulio ekonomika. Deja, pasaulis pasikeitè, 2020 m. pradžioje užklupus COVID-19 pandemijai. Siekdamos apriboti COVID-19 plitimą, vyriausybės visame pasaulyje ėmèsi drastiškų priemonių, uždarydamos visą šali ar labiausiai nukentẻjusius miestus, užverdamos sienas ir uždrausdamos patekti ị šalį, tai buvo didžiulis smūgis pasaulinei turizmo pramonei, ypač kelionių ir turizmo sektoriui (Fotiadis ir kt., 2021). Pandemija beveik sustabdè pasaulinę turizmo pramonę (Sharma ir kt., 2021). WTTC (2020), vertinančios COVID-19 poveiki turizmo ir kelionių sektoriui, 2020 m. lapkričio mèn. duomenimis, dèl pandemijos $2020 \mathrm{~m}$. prarasta 142,6 mln. darbo vietų (tai reiškia 43 proc. sumažèjimą), netekta 3,815 mlrd. USD pasaulio BVP (43\% sumažèjimas). Nustatyta, kad tarptautinių atvykimų skaičius pasaulyje sumažèjo 65 \%, atvykstančiujų šalies viduje - 33 \%. Prognozuojama, kad nesiimant veiksmų, kad situacija būtų pagerinta, šie nuostolius atskleidžiantys skaičiai dar augs. Netvari pramonès praktika nepadejjo sukurti ir išlaikyti gyvenimo darnos (Sharma ir kt., 2021). Taigi stebint didžiulị COVID-19 protrūkị, manoma, kad pasibaigus pandemijai, nebūtina grị̌ži prie tradicinio verslo modelio, ši situacija gali būti galimybẻ iš naujo įvertinti bendros turizmo sistemos pertvarką, siekiant darnumo (Gossling ir kt., 2020). Pandemijos akivaizdoje darnus regioninis požiūris gali būti ne tik būdas sektoriui išgyventi COVID-19 krizę, bet ir žingsnis tvaresnès ateities ekonominiu, sociokultūriniu bei aplinkosaugos požiūriu link. Todèl keliamas tyrimo klausimas, kaip COVID-19 pandemija paveiks turizmą ir ar tai lems perèjimą prie tvarios regioninès plètros.

Tyrimo problema. COVID-19 pandemijai užklupus pasaulį, turizmo ir kelionių sektorius pirmasis pajuto to padarinius - pateko ì nesaugią padètị. Tradiciniai turizmo verslo modeliai nustojo veikę. Kelionių ribojimas ir užsidarymas namuose ypač paveikè turizmo sektorių, kartu ir globalios ekonomikos vystymąsi. Turizmo skaičiai gerokai sumažejjo, tai paveikė ir ekonominius rodiklius. Turizmo ir ekonominių nuostolių prognozès rodo, kad norint išgyventi turizmo sektorių būtina pertvarkyti. Taigi galbūt ši krizinė padėtis gali turèti ne tik neigiamų padarinių, bet būti pokyčių turizmo sektoriuje stimulas, atliepiant darnesnị regioninị požiūrị.

Tyrimo tiks las: įvertinti COVID-19 pandemijos poveikị turizmui, atsižvelgiant ị tai, ar esami pokyčiai gali skatinti darnią regioninę plètrą.

Tyrimo objektas: COVID-19 pandemijos poveikis turizmui, ịvertinant tai, ar esami pokyčiai galètú lemti darnią regioninę plètrą.

Tyrimo uždaviniai:

- $\quad$ ivertinti COVID-19 pandemijos poveiki turizmui;

- ivvertinti turizmo iššūkius ir galimybes COVID-19 pandemijos akivaizdoje;

- ịvertinti galimus turizmo pokyčius siekiant darnios regioninès plètros.

Tyrimo meto dai: mokslinès literatūros analizè ir sintezè, statistinių duomenų analizè, situacijos modeliavimas, loginès išvados.

Analizè patvirtino, kad COVID-19 pandemija labai paveikè turizmo sektorių. Jos sukelti efektai pastebimi tiek globaliu, tiek regioniniu lygmenimis. Daugiau kaip 90 \% pasaulio gyventojų taikomi apribojimai 
(Gossling ir kt., 2020) lemia mažejančius pasaulio BVP, darbo vietų, atvykstančių turistų (tarptautinių ir vietinių) rodiklius. Pasauliui kovojant su pandemijos realijomis, galima permąstyti ateinančių dešimtmečių turizmo perspektyvas (Brouder, 2020). Nors krizinè situacija sektoriui kelia iššūkių, vis dèlto suteikia ir galimybių skatinti naujoves, pereiti prie naujų verslo modelių, ieškoti naujų nišų ar rinkų, atverti naujas vietas ir pereiti prie tvaresnių bei atsparesnių turizmo plètros modelių (EBPO, 2020). Ši pandemija prisidès kuriant naujus verslo modelius, kurie nulems pramonès išlikimo galimybes, paversdami ją daug tvaresne (Sharma ir kt., 2021). Kadangi pandemijos laikotarpiu pasauliniu mastu taikyti ribojimai ypač paveikè tarptautines keliones, tuo laikotarpiu daugiausia dèmesio skirta vietos - regioninio lygmens sprendimams. Regionas šio tyrimo kontekste suprantamas kaip teritorija, turinti atitinkamą valdžią ir teisę priimti tai teritorijai, regionui aktualius sprendimus. Analizuojant tarptautinio ir vidaus turizmo tendencijas pandemijos akivaizdoje, numatoma, kad pandemijos laikotarpiu ir jai pasibaigus triumfuos vidaus turizmas, kai dauguma keliautojų atvyksta iš netoliese esančių rajonų (Haywood, 2020). Manoma, kad vietinių gyventojų priklausomybès vietovei jausmas sudarys turizmo pramonès atgimimo sąlygas (Sharma ir kt., 2021). Kadangi COVID-19 pandemija pristabdè senojo netvaraus masinio turizmo modelio, kuris kenksmingas sociokultūriniu bei aplinkos požiūriu, plètrą, ši krizinè padètis galètų būti atspirties taškas pertvarką kreipiant darnesnio turizmo link. Ateities turizmas gali būti siejamas su tvaresniais mąstymo ir keliavimo būdais, nes keliautojai, atsižvelgdami ị COVID-19 pandemijos inicijuotus ribojimus, renkasi vietines, artimesnes regionines vietas, kartu mažiau kenksmingas transporto rūšis, taip labiau prisideda prie vietinès kultūrinès ir gamtinès aplinkos išsaugojimo. Keliautojams mąstant darniau, palaikant ir bendradarbiaujant vietos ar regionų vyriausybėms, turizmas, susidūręs su COVID-19 pandemija, galètų atsinaujinti ir igauti tvaresnę formą, taip prisidètų prie tvarios regioninės plètros. Taigi, kadangi vietinio - regioninio lygmens kelionės, vidaus turizmas šiuo sudètingu laikotarpiu galètų būti vienintelis keliavimo būdas, o COVID-19 pandemija laikoma tinkamiausiu turizmo sektoriaus pertvarkos laiku, atsakymas ị pagrindinį tyrimo klausimą, ar COVID-19 pandemijos poveikis gali lemti turizmo nukreipimą darnios regioninès plètros link, yra teigiamas.

Apibendrinant, be neigiamų padarinių, COVID-19 pandemija turejjo ir teigiamą poveikị, nes tai gali būti paskata keisti esamą turizmo modeli, siekiant tvaresnio turizmo ateities ir taip prisidedant prie tvarios regioninès plètros.

Šios išvados, patvirtinančios, kad COVID-19 pandemija - galimybė pakeisti turizmo sektorių siekiant tvaresnès regioninès plètros, galètų būti tolesnių tyrimų, analizuojant galimus pertvarkos turizmo sektoriuje sprendimus, bazè. Tyrimą būtų galima išplèsti detaliau analizuojant vietos ir regionų vyriausybių veiksmus siekiant sušvelninti COVID-19 pandemijos poveikị turizmo sektoriui ir visai ekonomikai bei atgaivinti sektorių ir pertvarkyti ji ateičiai, siekiant tvarios regionų plètros.

PAGRINDINIAI ŽODŽIAI: turizmas, kelioniu ir turizmo sektorius, COVID-19, pandemija, darnus regionu vystymasis.

JEL KLASIFIKACIJA: Z30, Z32, O18, L83.

Received: 2021-03-06

Revised: 2021-04-28

Accepted: 2021-05-04 